\title{
Crossing Language Borders - as Shown by the Historical Dictionary of the Hungarian Language in Transylvania ${ }^{1}$
}

\author{
Borbála ZSEMLYEI \\ Department of Hungarian and General Linguistics \\ Babeş-Bolyai University, Cluj-Napoca \\ zsemlyei@yahoo.com
}

\begin{abstract}
Transylvania has always been a space of multiculturalism, which is reflected in the fact that the Hungarian regional standard contains more Romanian and German elements than the central standard. And that is not only peculiar to the present state of the language, but it is a historical phenomenon. During the process of editing the Historical Dictionary of the Hungarian Language in Transylvania, Attila Szabó T. and his co-workers realized that the language material gathered from Transylvanian archives contains a number of Hungarian words of Romanian origin that the literature has no knowledge of. Thus came the idea of a smaller dictionary which would present the Romanian loan words of Hungarian spoken in Transylvania in the period of the $16^{\text {th }}-19^{\text {th }}$ centuries. By the mid-1980s, the editorial work was finalized; however, it has never been published - the material is kept at the Department of Hungarian and General Linguistics, Babeş-Bolyai University, Cluj-Napoca. In my paper, I will attempt to present the words of Romanian origin listed in the Historical Dictionary of the Hungarian Language in Transylvania, which the general literature of loan words has no knowledge of in the context of crossing borders, in the sense that neighbouring languages always have a huge impact on each other even if they are completely different genetically.
\end{abstract}

Keywords: Romanian-Hungarian language contact, loan words, Historical Dictionary of the Hungarian Language in Transylvania

\section{Introduction. Languages in contact}

It is a linguistic commonplace that languages living next to each other in the same geographic region influence each other in various ways. Language interference has been studied for several decades already, one of the earlier definitions being

1 This study was presented at the AHEA Conference in Cluj (July 2015). 
"those instances of deviation from the norms of either language which occur in the speech of bilinguals as a result of their familiarity with more than one language, i.e. as a result of language contact” (Weinreich 1968: 1).

Another linguistic commonplace brings into play the main characteristic of language contact, which is that loan words are usually culture specific to the language they come from (Benő 2008: 60).

These two commonplaces are particularly characteristic to Transylvania, which has always been a space of multiculturalism reflected in the fact that the Hungarian regional standard contains more Romanian and German elements than the central standard. And that is not only peculiar to the present state of the language, but it is a historical phenomenon.

\section{The case of Transylvania - historical background}

The population of Transylvania is ethnically, linguistically, and religiously diverse. In the Transylvania of the $\mathrm{XV}^{\text {th }}-\mathrm{XIX}^{\text {th }}$ centuries, the political power was shared among the Hungarian nobility, the German burghers, and the seats of the Székelys; yet, the population - besides Hungarians and Germans - consisted of Romanians as well. The Romanians did not take part in the political life of Transylvania, but they belonged to the lower social classes; thus, the Hungarian-Romanian language contact took place among lower social classes.

As it can be seen in Map 1, by 1850, there were several counties in Transylvania (Arad, Timiş, Caraş-Severin, Hunedoara, Alba, Cluj, Bistrița, Sibiu) that had a majority of ethnic Romanians, while Hungarians were in majority in Bihor, Satu-Mare, Mureş, Harghita, and Covasna. This means that $58 \%$ of the population was Romanian, $28.2 \%$ Hungarian, and 10.6\% German (http://terkepek.adatbank. transindex.ro/belso.php?nev=78).

Therefore, it is natural that the Romanian language (purple dots on Map 2) was widely spoken on the territory of Transylvania.

Under these geographic, ethnic, and cultural circumstances, the Hungarian language (mainly but not only) used in Transylvania has been largely influenced by the surrounding Romanian language. As the two languages are not genetically related, the lexical system suffered the most influence, whereas other systems, such as the morphological or syntactic system, did not undergo major changes - yet, the effect of Romanian can be detected on all levels of Hungarian used in Transylvania.

It is a linguistic commonplace that the loan words usually are culture specific to the language they come from (Benő 2008: 60); thus, all borrowings reflect the Romanian lifestyle in one way or the other.

At present, there are 122 Romanian elements in the standard register of Hungarian, that is the use of these words is not restricted to Transylvania (e.g. 


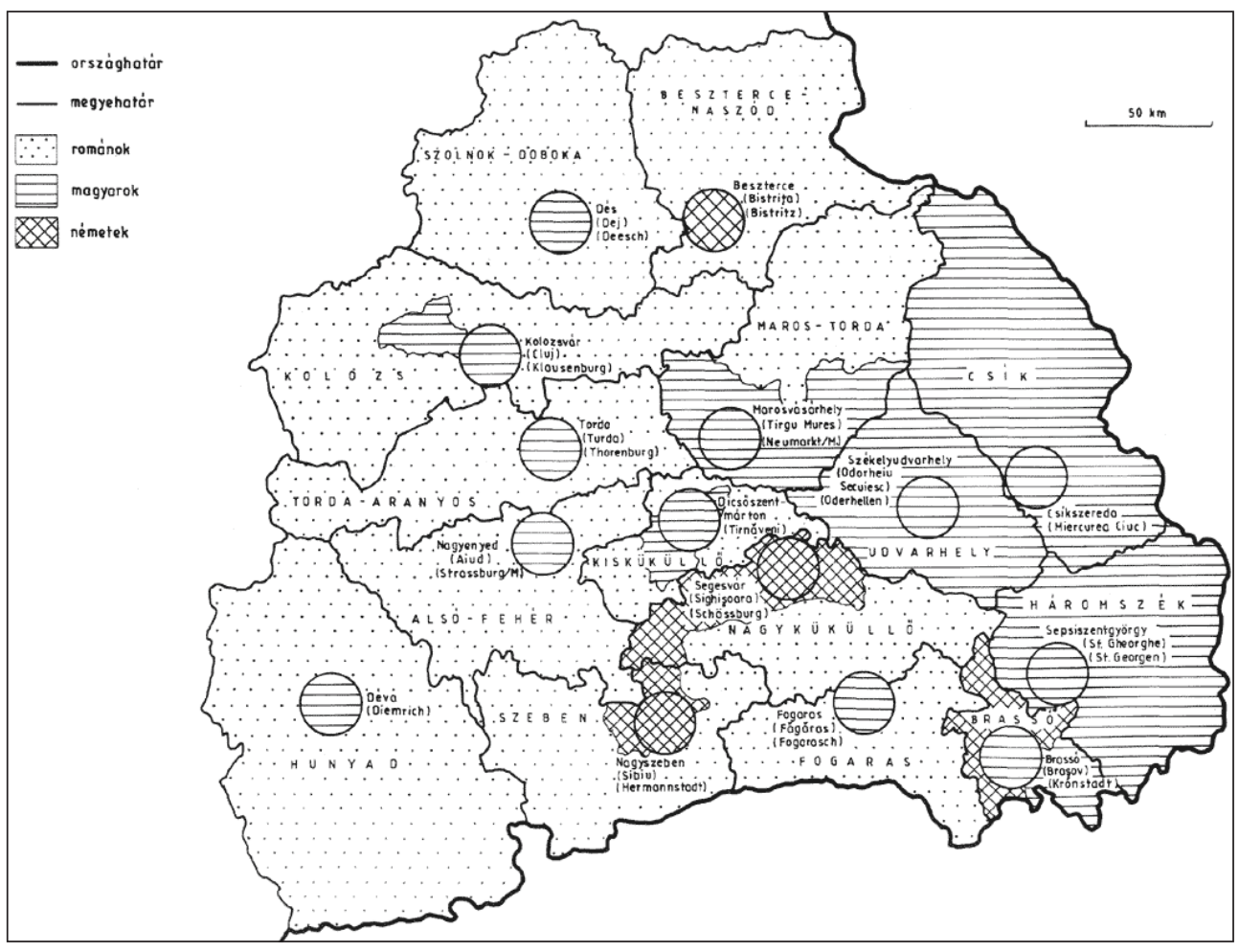

Map 1. The ethnic situation of Transylvania in $1850^{2}$

esztrenga 'primitive fence to keep the sheep in one place', cáp 'male goat', etc.). The Hungarian dialects of Transylvania are richer in Romanian loan words: there is a total of 2,300 elements of Romanian origin.

Table 1. Chronological aspects of Romanian loan words (Bakos 1982: 378)

\begin{tabular}{ccc}
\hline Century & Number of words & Example \\
\hline 14. & 4 & kosár 'basket' \\
\hline 15. & 10 & kaliba 'hut' \\
\hline 16. & 53 & cimbora 'friend' \\
\hline 17. & 80 & furulya 'flute' \\
\hline 18. & 134 & áfonya 'blueberry' \\
\hline $1800-1871$ & 176 & cujka 'brandy' \\
\hline $1872-1900$ & 383 & lej 'Romanian currency'
\end{tabular}

2 The dotted area represents Romanians, the striped area Hungarians, and the chequered area Germans. 


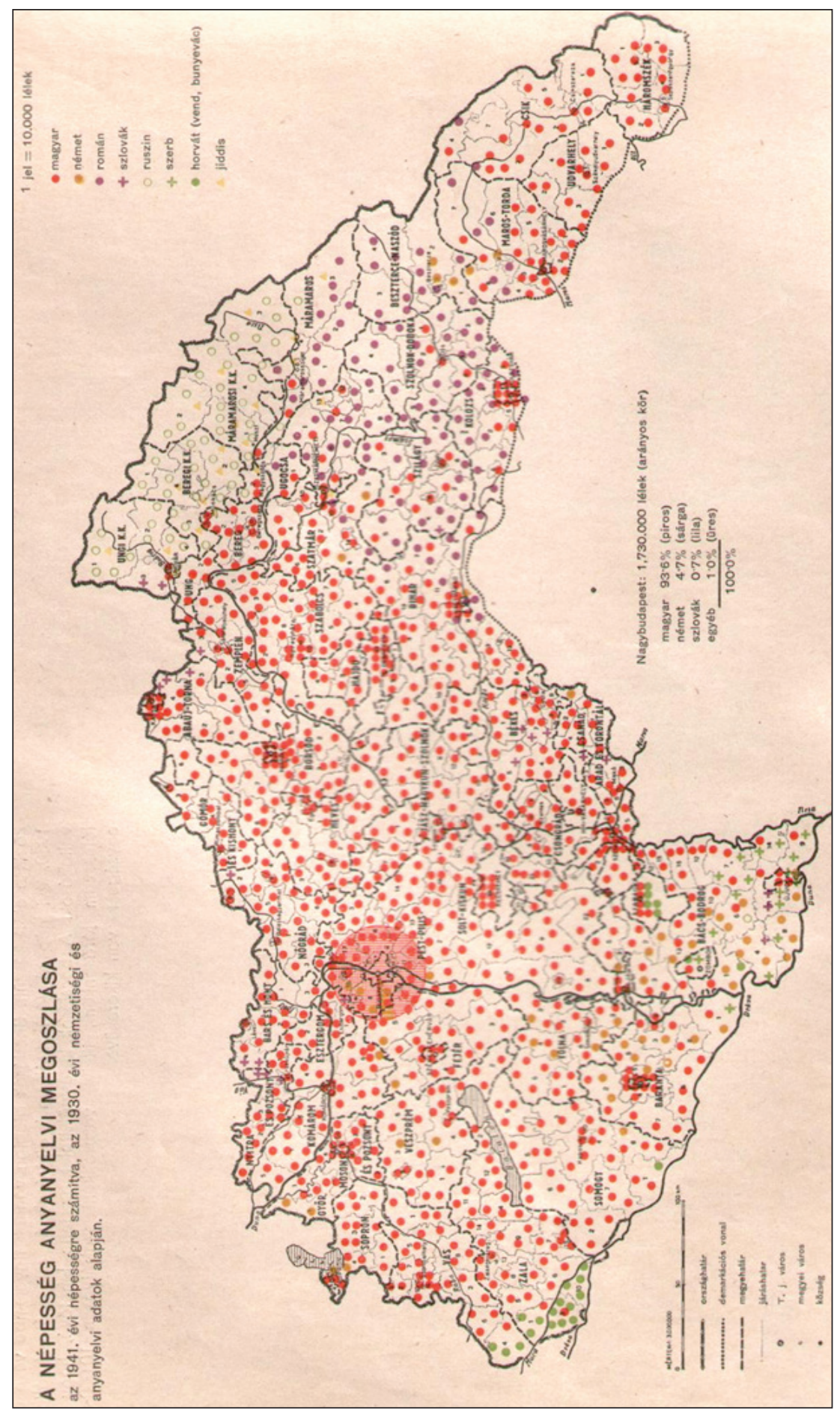

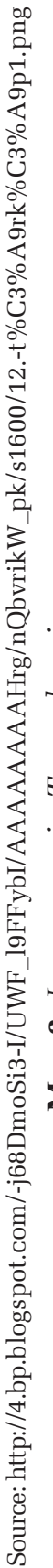


The table above shows the number of Romanian loan words appearing in Hungarian in every century, starting with the $14^{\text {th }}$. It can be very well seen that the number increases from century to century, reaching its peak in the $19^{\text {th }}$ century. The table does not include any data from the period following Trianon, which - due to the political, geographic, and demographic changes - had the strongest Romanian influence, as the status of the two languages in contact changed: Romanian becoming the official language and Hungarian a minority language.

\section{Previous research of the Romanian influence on Hungarian (dialects)}

The first steps into the research of Romanian-Hungarian contact date back to the $19^{\text {th }}$ century. In his work Vocabularium (1816, Vienna), Sámuel Gyarmathy proved the Romanian origin of several Hungarian loan words. János Gáspár, József Vass, and Pál Hunfalvy dealt with smaller details of the matter. Antal Edelspracher listed 142 words of Romanian origin in his study Rumun elemek a magyar nyelvben [Romanian elements in Hungarian] (1876). In the Magyar Tájszótár [The dictionary of Hungarian Dialects] (1893-1901) edited by József Szinnyei, a number of 340 words were proved to be of Romanian origin, and the list was later completed by Gergely Moldován with data from Alsófejér County. István Damian in Adatok a magyar-román kölcsönhatáshoz [Data to the Romanian-Hungarian influence] (1912, Budapest) added a further 200 words to the existing list. The only Romanian study was written by Géza Blédy, Influența limbii române asupra limbii maghiare. Studiu lexicologic [The influence of the Romanian language on Hungarian. A lexicological study], which appeared in 1942 in Sibiu, and it already mentions 570 words. A thorough monography of the Romanian elements in the Csángó dialect, A moldvai csángó nyelvjárás román kölcsönszavai [The Romanian loan words of the Csángó dialect in Moldova] was authored by Gyula Márton and appeared in 1972. The most extensive work on this matter was published by Gyula Márton, János Péntek, and István Vöő, A magyar nyelvjárások román kölcsönszavai [The Romanian loan words of the Hungarian dialects] (Bucharest, 1977), and it contains 4,243 words.

A field less researched is that of the Romanian and Hungarian language contact from a historical perspective. There are very few studies that attempted to give a chronological analysis of the Romanian influence on Hungarian. György Alexics (1911) put together a list of the words of Romanian origin in the army lexicon. István Takáts in his work Rajzok a török világból [Sketches from the Turkish period] (Budapest, 1915) presented words related to shepherding. Ferenc Bakos published the most detailed monography with the title A magyar 
szókészlet román elemeinek története [The history of the Romanian elements of the Hungarian lexicon] (Budapest, 1982).

\section{The data of the Historical Dictionary of the Hungarian Language in Transylvania as a valuable source of the Romanian-Hungarian interference}

The Historical Dictionary of the Hungarian Language in Transylvania contains the complete vocabulary of the Hungarian language used in Transylvania in the period of the $15^{\text {th }}-19^{\text {th }}$ centuries. It is unique in the sense that it reflects the spoken language since it was the policy of legal processes in the period mentioned above that the witness accounts had to be registered precisely, word by word, stating the name, age, job, and social status of the witness. Therefore, words of Romanian origin are included either as entry words or appear in the witness accounts of Romanian witnesses.

The borrowings from Romanian can be grouped into the following categories: ${ }^{3}$

1. the human (body parts, illnesses, cures, life, characteristics, etc.) (bába ‘old woman’ 1749: Mitru ... Pop Urszult öszve szidá azért hogy azt monad néki, miért sir mint egj bába, és belé garázdálkodék részegen Mitru Urszulba, tépelődni kezdé(ne)k [Szentbenedek SzD; MvRk]; muntyán 'man living in the mountains' 1700: Az utrumban Specificalt Személlyeknek az Attyokat hitták Opris Peter(ne) k; és nem Csonokosi örökös jobbágj vólt, hanem Havasoly földi Muntyán volt és onnan származat ki [H; Szer. Dumitru Sandon (50) jb vall.].);

2. kinship and other human relations (fáta 'Romanian girl' 1661: De talám azért nem jutott eszedben, gondolád, nem fiókád, hanem fátád leszen; az is enyém leszen, én fáradságomnak munkája, nem tied [TML II, 176 Teleki Mihály feleségéhez, Veér Judithoz]; kumnát 'brother-in-law' 1725: Barna Birtolomély... Circiter 8 Esztendeje aufugialt; és most Besztercze székben egy Sude Paskuly nevû Cumnattyoknál commorál [Körtvélyes SzD; BK. Buta Birtolomej (78) vall.]);

3. clothing (kalcun 'a type of boots' 1802: Nyikuláj Szláva ... fekete Czondrában, fejér harisnyába, és rövid Káltzunba (: Tzöpökbe :) [DLt nyomt. Kl]; kozsók ‘a type of coat' 1619: Tudom azt hogj Gwtteo Peter feyet keote Beczj imreh Vramnak ket rendbelj latorsagaert giapiaknak es kosoknak lopasaert [BLt 3 Debreczj Balas Z.Martonj (70) ppix vall.].);

4. foods and drinks (hiribigomba 'a kind of mushroom that grows in the forest: porcini’ 1855: A jobbágy felesége ... Ősszel fél véka mogyorót, két fúzér hiribi gombát, félkupa kömény magot ... ád [ÚjfE 181]; orda 'special kind of cheese'

3 The examples are taken from the Historical Dictionary of the Hungarian Language in Transylvania. 
1548: Továbbat ím az kecskéhez majort költem, ki mind sajtját, ordaját, berenczéit uaját megtudja czinálnia [Fog.; NádTLev. 137 Nádasdy Tamáshoz].);

5. the house and its surroundings (kaliba 'small hut' 1570: Brassay Symon, Megh eskwek es ezt valla ... Mykor az vyzztay ember haytia volt Eokreit az Talas Mathe zeleye gepwye mellet ... Az Talas Mathe haygalny kezte feoldel es karo Darabal az Eokreket Az vyztay ember azon keppen Matet ... Mathe az kalibaban fwtot, Zabliat Es egy darab karot hozot ky kezebe [Kv; TJk III/2. 46]; kilim 'colourful carpet' 1656: Ket tarka viseltes veresses szeönyeg, Edgik az Aztalon ... Ket tarka kilin; Edgik uy, az masik viseltes [Doboka; Mk Inv. 2 néhai Magyarvéggyantai Boros János inv.]);

6. stock-raising (bács 'shephard' 1569: hitwan baczynak hozasayrt ew maga marazta harmincz keth forinton. Zabo Mathe harmincz keth forintig volt kezes az hitwan baczynak hozasairt [HSzj]; berbécskirián 'young tup' 1782: Fejer nagy Juh ... Fejér Kirlán ... fekete Kirlán ... Fejer nagy Berbécs ... Fejér berbecs Kirlán ... Fekete berbecs Kirlán [Mezősámsond MT; Berz. 5. Fasc. 42. S. 84]);

7. other rural activities (kaláka 'voluntary work' 1785: mikor Néhai Sámuel Diák a’ csûrét éptette tudom, hogy kalákát kére é sot vala kalákába szarvazni Réti Csutak István Uram is [Kovászna Hsz; HSzjP Sigismundus Sigmond (32) ns vall.]; podvoda 'compulsory work' 1780 k.: a' Borgai Joszág ... két rendben egy esztendöben küldettetett Padvodába [FogE 196].);

8. nature (lunka 'plough-land' 1617: Abrugifalvi hatarb(an) az meli Lunka ide ala vagion Istuan deaknal szalagb(an) huz forintb(an) egienlokeppen valcziak ki es osztozzanak [Abrudbánya; Törzs]; pojenica 'small grassy field in the forest' 1782: azt tudom hogy égy hellyetskét a Gorbai határon in vállyá Unguruluj nevezetú vőlgyben Pojáná Boldizsojénak hivják melly Pojenitzát én tudom, hogy olly kitsiny helly volt tsak az én emlekezetemre is, hogy alig termett meg rajta égy szekeretske széna... de ezen Pojenitzát miért hivják annak, nem tudom [Paptelke SzD; JHbK VIII/18 Petrán Togyér Senior (72) jb vall.].);

9. industry, trade, money, and measures (izlot 'old money' 1636: az mi kegyelmes urunk eö nagysaga kegjelmesen engette megh hogi Moldvaba be küldhessek egi Konztantin nevü bojer baratomhoz ... az melly Bojer Konztantin nevw nekem ados volt ... es marattam adossa neki eötven eöt zlottal [Gyeke K; Hurm. XV/II, 1021 Vesselenyi Boldizár Beszt-hez]; patrarica 'a quarter of a given money’ 1836: Rettegi Sándor Urnak Cselédgyei a malombol menet Haza felé meg állottak, az Uttzán ... a kik én hozzám bé jôvén pálinka innya, bé jővetelekkel egy Tébujétzban egy vékánnyit hoztak bé Gabonával ... az édgyik Cseléd ... azt a Tébujétzot a Szekérhez ki vitte, és Tőrőkbuzát hozott osztán bé, pálinkáért mit egy Patraritzát fizettek Szemeim előtt [Kendilóna SzD; RLt Zsimán Silipp (52) vall.].);

10. culture, traditions, customs, entertainment, games, and superstitions (batuta 'a kind of Romanian folk dance’ 1775-1806: Kótyászó szerelmü szép Fátákat láttam 'S Tráján’ jobbágyival batutát is jártam [(Révai Miklós) Két nagyságos elme 91]; kolindálás 'Christmas carolling' 1752: Tudgyaé a Tanu nyilván, és bizonyoson 
... hogy ennek előtte Cir(citer) hat esztendővel Ns Hunyad v(árme)gyéb(en), All Gyogyon ... Alb Opra nevú Jobbágya Házához, az oláhok szokások szerént Karátson bőjtin, kik szoktanak volt kolindilás (!) véget étzakánként Conflualni, nevezze meg a Tanu [BK vk].);

11. politics, administration, army, religious life, and church (beszerika 'church' 1645: It Kis Budako(n) liuei olah attjafiak ez el mult üdökb(en) az Beszerikajokbul ugjan alkalmas kart valuan, az mely Papiok akkor tayba(n) itt lakot az Vejuel eggiüt arra vagio(n) minde(n) erős Gjanosagok [Kisbudak BN; RLt Retteghj István lev.]; kununáltatja magát 'gets married' 1762/1845: kőszönje a' Leány is, hogy Apjával vagy oláh Pappal nem kununáltatta magát [Hermányi, EDem. 316-7].).

As the Historical Dictionary of the Hungarian Language in Transylvania contains such a great number of valuable data regarding the Romanian-Hungarian language contact, the idea of another dictionary occurred during the process of editing: a dictionary that would contain all the words of Romanian origin in the Hungarian dialects of Transylvania: A magyar nyelv feudalizmuskori román kölcsönszavai [The Romanian loan words of Hungarian in the feudalist period]. The editorial work of this dictionary was completed by the mid-1980s by Piroska B. Gergely, Ferenc Kósa, Zoltán Szabó, Márta Vámszer, and János Zsemlyei, but it has never been published. It followed the editorial principles of the Historical Dictionary of the Hungarian Language in Transylvania except that the words were grouped in lexical families. For example: berbécs - all words containing berbécs either in compounds or derivatives can be found in the same place: berbécs/berbécsbárány, -bőr, -bőrirha, -címer, -gyapjú, -forma, -hús, -juh-bőr, -kirlán, -láb, -mióra, -orrú, -pásztor, -pecsenye/diszkeberbécs, diszkeberbécs-bárány, diszke vert berbécs, juhberbécsbőr, kirlánberbécs, kos-, majorság-, mióra-, -nótin-, vert berbécs.

\section{Project for the future}

The edited material is kept at the Hungarian and General Linguistics Department, Babeş-Bolyai University. The dictionary contains around 1,255 entry words. It would be necessary to revise the material in the light of new bibliography and prepare it for publishing.

The dictionary would be a great source for researchers studying contactology, historical linguistics, historical sociolinguistics, historical pragmatics, etc. 


\section{References}

Bakos, Ferenc. 1982. A magyar szókészlet román elemeinek története. Budapest: Akadémiai Kiadó.

Benő, Attila. 2008. Kontaktológia. A nyelvi kapcsolatok alapfogalmai. Kolozsvár: Egyetemi Műhely Kiadó-Bolyai Társaság.

Márton, Gyula-Péntek, János-Vöő, István. 1977. A magyar nyelvjárások román kölcsönszavai. Bucharest: Kriterion Könyvkiadó.

Weinreich, U. 1968. Languages in contact: findings and problems. The Hague: Mouton \& Co. N.V. Publishers. 